\title{
Diagnostic study of FMD virus in different area in Iraq
}

\author{
Ameen Ahmad Sabar ${ }^{1}$, Anton S. Al-Banna ${ }^{1}$, Laith MS. Abdul-Rasoul ${ }^{2}$ \\ and Barraq K.Abood ${ }^{2}$ \\ 1- Department of microbiology, Coll. Vet. Med. /Univ. of Baghdad 2- General State \\ Company for Veterinary Services
}

\section{Summary}

Seventy four (74) samples from cattle, buffalo, goat and sheep were tested to isolate the FMD virus, 23 isolates of the virus showed Cytopathic Effect (CPE) on the different types of cell culture.

The CPE appears after 24 hours on fetal lamb kidney (FLK) cells, 48 hours on the fetal bovine kidney (FBK), 30 hours on primary Fetal Bovine Thyroid cell (BTY) and 20 hours on the primary fetal ovine thyroid cells (OTY). Solid phase ELISA test showed three serotypes of FMD virus O, A and Asia1. One step real time RT-PCR for the diagnosis of FMDV by using 5UTR FMDV primers and taqman probe (SA-IR-219-246F, SA-IR-315-293R and SAmulti2-P-IR-292-269R). Samples were tested, showed 23 positive machines by using the Applied Biosystem Fast 7500 real time PCR.

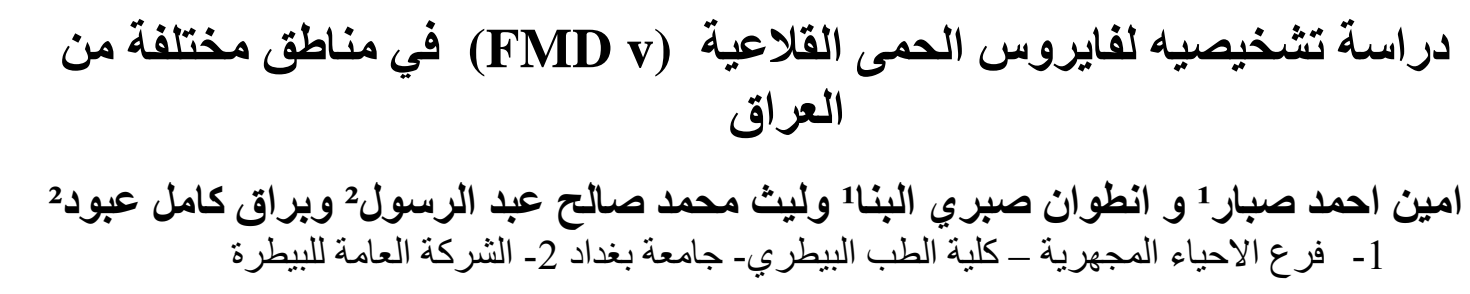

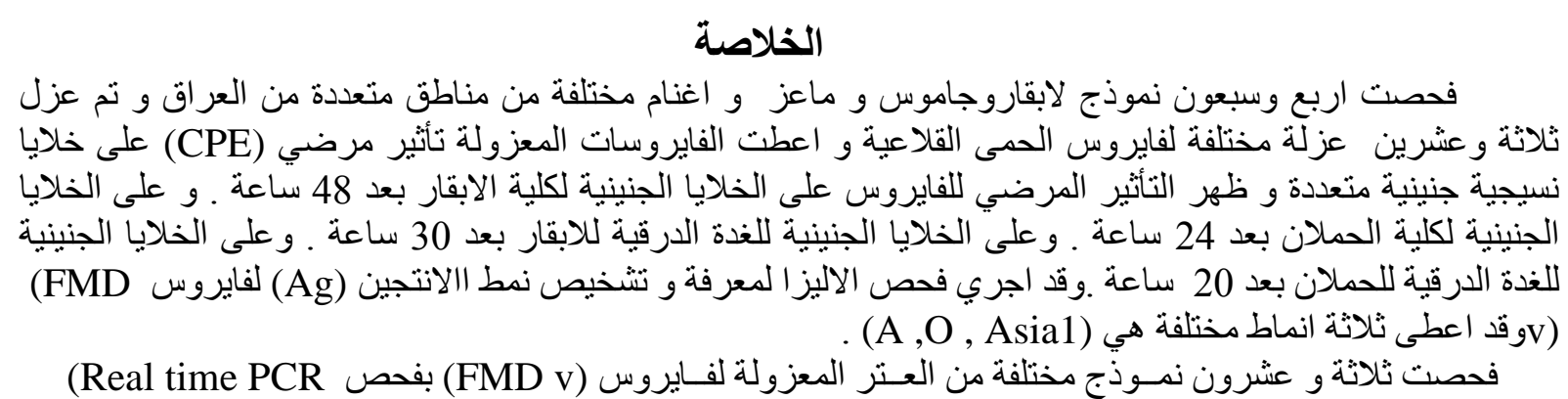

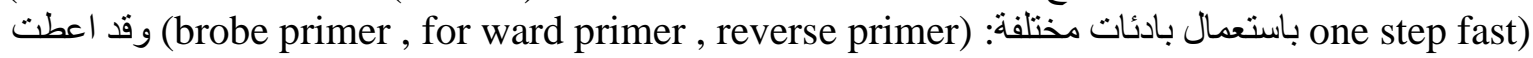

\section{Introduction}

نتيجة موجبة.

Foot and mouth disease (FMD) is the most contagious disease of mammals and has a great potential for causing severe economic loss in susceptible cloven-hoofed animals. There are seven serotypes of FMD virus (FMDV), namely O, A, C, SAT 1, SAT 2, SAT 3 and Asia 1. Infection with one serotype does not confer immunity against the others. FMD cannot be differentiated clinically from other vesicular diseases, such as swine vesicular disease, vesicular stomatitis and vesicular exanthema (1).

The virus belongs to the genus Aphthovirus in the family Picornaviridae. The virus genome is an 8.5-kilobase $(\mathrm{kb})$ Single strand RNA in the plus orientation, carrying a poly a tract at its 3' end and a viral genome protein (VPg) and poly $\mathrm{C}$ at its $5^{\prime}$ end. $(3,6)$ The virion, an icosahedral capsid, consists of 60 copies of each of the four proteins, VP1-4, of which VP1 is the main protein determining antigenic Identity $(1,10)$. The differences in VP1 sequences are the basis for developing reverse transcriptase polymerase chain reaction (RTPCR) tests to identify different serotypes multiplex-PCR.

The A Iran 05 topotype, belonging to the Asia top type, is the predominant serotype a lineage circulating in the Middle East. It has two different paths of evolution: the A22 
sublineage as starting point and A/IRN/05, A-Iran-96 and A-Iran-99 as evolutionary intermediates (12).

In Turkey, in 2007, the new sub-lineages A-Iran-05ARD-07 and A-Iran-05EZM-07 were observed and were predominant in this country. These strains are now presented in most of the Middle Eastern countries and has reached since the beginning of 2009 Bahrain, Kuwait, Lebanon, Libya and Iraq. The new epidemic sub-lineage reported in the above countries and circulating (11)

According to the FAO report 1999 the common serotypes isolated in Iraq from 1952 to 1998 were A, O Sat1 and Asia 1(19)

In 1988 Virus was isolation, serotyping and characterization of FMD disease in Iraqi Native Gazella (17). In 1998-2000 outbreak of the disease occur in Iraq, and the virus was isolated from Holstien cattle and characterized as $\mathrm{O}$ serotype. (18)

In Iraq 2009 outbreaks samples sent to Pirbright in subtypes as a related to Turkish isolates. The most closely related virus isolate A / IRQ / 24 / 2009 was matched $\mathrm{A} / \mathrm{IRQ} / 10 / 2009$ with $99.69 \%$ of identity and to A/KUW/6/2009 isolate with $99.69 \%$ and to A/IRN/1/2005 with $95.46 \%$ and A/SAU/41/91 isolate with $84.75 \%$ and finally to A22/IRQ/24/64 (vaccine strain) with $82.16 \%$ identity (21).

The aim of this study: due to continuous spread of Foot and Mouth Disease in the country, and the lack of appropriate diagnostic aid which facilitate to identify and sub typing of our viral isolates, beside lack of ideal vaccines to match field viruses, our aim was to follow indepth steps which are beneficial to answer many questions concerning foot and mouth disease and the causative agent circulating in the country

\section{Materials and Methods}

SAMPLES : The biological samples were collected from 51 cattle, 9 sheep, 11 buffaloes and3 goat from epithelial tissue of tongue and gums(44samples), interdigital vesicles(6 samples ), vesicular fluid(17 samples )and esophageal swap (7 samples ). From affected animals (total 74 samples).samples were processed with PBS (pH 7.4-7.6) centrfugation 4000 rpm for $10-15$ min.at $4{ }^{\circ} \mathrm{C}$.

Streptomycin + penicillin were added to the supernatant fluid. The studies included 7 types of tissues

CELL Cultures :(All of fetal origin)Primary bovine thyroid, ovine thyroid, lamb kidney, bovine kidney ,bovine tongue, sheep and bovine testis, Prepared by using trypsin $0.25 \%$ for getting the primary confluent monolayer cell culture (20).

VIRUS ISOLATION: Confluent monolayer in $25 \mathrm{~cm} 2$ disposable plastic flasks was inoculated with $0.5 \mathrm{ml}$ of the processed samples. Incubated for $1 \mathrm{hr}$. at $37{ }^{\circ} \mathrm{C}$, following the addition of $2 \mathrm{ml}$ of Eagle MEM without serum, the flasks were incubated for more than 48hrs at $37{ }^{\circ} \mathrm{C}$ and the infected cultures were daily examined microscopically to check the appearance of cytopathogenic effects (CPE) in the case of lack of the CPE, the cells cultures were frozen and then thawed and used to inoculate fresh cultures (second passage). The specificity of the virus was checked by the detection of the viral antigen using the antigen detections -ELISA.

VIRAL RNA EXTRACTION: The total RNA was extracted using trizole-reagent according to the manufacturers Protocol (Ambion).

REAL TIME RT-PCR (rRT-PCR). The method was followed by one Taq has Primer/probe set from internal ribosomal entry site(IRES)sequences.(within the FMDV RNA $5^{\circ} \mathrm{c}$ untranslated region.UTR)was as follows :

SA-1R-21q-246-forward primer):(5'-CACYTYAAGRTGACAYTGRTACTGGTAC-3').

SA-1R-315-293R (reverse primer):(5'-CACYTYAAGRTGACAYTGRTACTGGTAC $\left.3^{\prime}\right)$.

FMDV IRES probe sequence: SAmulti 2-p-IR-292-269R(TaqMan probe):- :(5'CACYTYAAGRTGACA YTGRTACTGGTAC-3'). 
The rRT-PCR was performed in micro Amp optical 96-well reaction plate (Applied Biosystems) in one -step reaction using one step RTPCR KIT. (Ambion Ag path-IDTM) enzyme mixture.

The reaction mixture at the volume of $20 \mu$ l. contained $12.5 \mu \mathrm{l}$ of $2 \mathrm{X}$ RT-PCR buffer, RT-PCR enzyme mix X $251 \mu \mathrm{l}$ forward primer 10 pmol, $(0.2 \mu \mathrm{l})$ Taq man probe $0.1 \mu \mathrm{l}(10$ pmol. Rnase free water $6 \mu 1$ and $5 \mu 1$ of extracted RNA was added to the reaction mix (total volume $25 \mu \mathrm{l}$ ) and the reaction was capped using optical caps (Applied biosystemes).The plate was transferred to the thermocycler (7500 fast real time PCR system, Applied Biosystemes) and amplification was carried out using the following program: $45^{\circ}$ cfor $10 \mathrm{~min}$ (one cycle) for reverse transcription and $95^{\circ} \mathrm{C}$ for $10 \mathrm{~min}$ (one cycle)to activate the DNA polymerases and inactivate the reverse transcriptase and 40 cycles at $95^{\circ} \mathrm{C}$ for $15 \mathrm{sec}$. and at $60^{\circ} \mathrm{C}$ for $45 \mathrm{sec}$. Fluorescence was measured at the end of the $60^{\circ} \mathrm{C}$ annealing /extension step. And cycle threshold $(\mathrm{Ct})$ value was determined at three point on the $\mathrm{X}$-axis showing the number of cycles of replication where the fluorescence breached a threshold fluorescence line after the amplification.

\section{Results}

The results of the isolation of the FMD in cell cultures are shown in table -1-: The presence of infectious FMDv was found in 23 examined samples from 74 samples, all the positive 23 isolates produced a visible cytopathogenic effect in the first passage after 20 hour .post inoculation (pi) in primary fetal ovine thyroid cells, and also produced visible CPE in second and third cell culture subpassages (fig. 1,2) while produced visible CPE in the first passage after 30 hours. post inoculation in primary fetal bovine thyroid cell (BTY) only, and No CPE was detected in the second subpassage of BTY cells.All the positive 23 samples isolates produce a visible CPE in the first passage after 24 hours. (Pi) in the fetal lamb kidney and produced a visible $\mathrm{CPE}$ in the $\mathrm{P} 2, \mathrm{P} 3$ and $\mathrm{P} 4$ of the fetal lamb kidney. While in fetal bovine kidney produced a visible CPE in first passage after 48 hours. (Pi) for the samples (120) and the remaining 3 samples caused a visible CPE after 48 hours. Post inoculation in the second passage of the virus. While in Fetal bovine tongue cells showed weak CPE after 96 hours. Post inoculation in the secondary passage of the virus. However the fetal sheep testis and fetal bovine testis cell did not show any CPE after 10 days (pi) in the second and third passage of the virus.

The identification of the serotypes of the virus responsible for the CPE was performed by Ag-ELISA (Table 2).

The identification of the virus causing the CPE was performed by Ag-ELISA (12 of serotype $\mathrm{O}, 10$ of serotype Asial and 1of serotype A), were found in 23 FMD samples (Table 2).

The result of the real-time RT-PCR (rRT-PCR) assay was evaluated by the Ct value. All FMDv isolates tested by rRT-PCR were recognized as positive ( $\mathrm{Ct}<40.0)$ (Table 2.). However FMDv RNA was undetectable in the epithelium collected from healthy uninfected calf (K-) negative control. 
Proceeding of the Eleventh Veterinary Scientific Conference, 2012; 53-55

TABLE -1- The results of the isolation of the FMDV in different types of cell culture.

\begin{tabular}{|c|c|c|c|}
\hline Types of cell culture & $\begin{array}{l}\text { NO. of passages of } \\
\text { cell culture }\end{array}$ & Cytopathic effect /hour & $\begin{array}{l}\text { No. of viral isolates/ cell } \\
\text { culture passages }\end{array}$ \\
\hline Fetal ovine thyroid cell & $\begin{array}{l}\text { 1st, 2nd, 3rd, 4th and } \\
\text { 5th }\end{array}$ & 20 & $\begin{array}{c}23 \text { isolates/1st, } 2 \text { nd and } \\
3 \text { rd }\end{array}$ \\
\hline $\begin{array}{l}\text { Fetal bovine primary } \\
\text { thyroid cell }\end{array}$ & 1st culture only & 30 & $\begin{array}{c}23 \text { isolates } / 1 \text { st, } 2 \text { nd and } \\
\text { 3rd }\end{array}$ \\
\hline Fetal lamb kidney & $\begin{array}{l}\text { 1st, 2nd, 3rd, 4th, 5th, } \\
\text { 6th, 7th and 8th. }\end{array}$ & 24 & $\begin{array}{c}23 \text { isolates } / 1 \text { st, } 2 \text { nd and } \\
3 \text { rd }\end{array}$ \\
\hline Fetal bovine kidney & $\begin{array}{l}\text { 1st, 2nd, 3rd, 4th, 5th, } \\
\text { 6th, 7th and 8th }\end{array}$ & 48 & $\begin{array}{l}20 \text { isolates } / 1 \mathrm{st} \\
3 \text { isolates } / 2 \mathrm{nd}\end{array}$ \\
\hline Fetal bovine tongue & 1st, 2nd and 3rd & Up to 96 hours & 23 isolates/ 2 nd \\
\hline Fetal bovine testis & 1st, 2nd, 3rd and 4th & $\begin{array}{l}\text { No CPE up to } 10 \text { days in } \\
\text { p1, p2 }\end{array}$ & $\begin{array}{c}\text { No isolate }(\mathrm{CPE}) / 4 \\
\text { passages }\end{array}$ \\
\hline Fetal sheep testis & 1st, 2nd, 3rd and 4th & $\begin{array}{l}\text { No CPE up to } 10 \text { days in } \\
\text { p1, } 22\end{array}$ & $\begin{array}{c}\text { No isolate }(\mathrm{CPE}) / 4 \\
\text { passages }\end{array}$ \\
\hline
\end{tabular}

TABLE -2-: The results of detection of FMD vin biological material involve both AgELISA and rRT-PCR

\begin{tabular}{|c|c|c|c|c|}
\hline no. & SAMPLE No. & $\overline{A g-E L l}$ & & rRT-PCR \\
\hline & & TYPE & TITER & \\
\hline 1 & Am OO1 & $\mathrm{O}$ & 0.673 & $+\mathrm{Ve}$ \\
\hline 2 & Am OO2 & Asia 1 & 1.377 & $+\mathrm{Ve}$ \\
\hline 3 & $\mathrm{Am} \mathrm{OO3}$ & Asia 1 & 2.127 & $+\mathrm{Ve}$ \\
\hline 4 & $\mathrm{Am} \mathrm{OO4}$ & Asia 1 & 1.613 & $+\mathrm{Ve}$ \\
\hline 5 & Am OO6 & Asia 1 & 0.408 & $+\mathrm{Ve}$ \\
\hline 6 & Am OO9 & Asia 1 & 1.226 & $+\mathrm{Ve}$ \\
\hline 7 & Am O10 & Asia 1 & 0.745 & $+\mathrm{Ve}$ \\
\hline 8 & Am 012 & $\mathrm{O}$ & 0.244 & $+\mathrm{Ve}$ \\
\hline 9 & Am 015 & $\mathrm{O}$ & 0.340 & $+\mathrm{Ve}$ \\
\hline 10 & $\mathrm{Am} \mathrm{O17}$ & $\mathrm{O}$ & 0.214 & $+\mathrm{Ve}$ \\
\hline 11 & Am 018 & $\mathrm{O}$ & 0.166 & $+\mathrm{Ve}$ \\
\hline 12 & Am 019 & $\mathrm{O}$ & 0.722 & $+\mathrm{Ve}$ \\
\hline 13 & Am O20 & $\mathrm{O}$ & 0.370 & $+\mathrm{Ve}$ \\
\hline 14 & $\mathrm{Am} \mathrm{O} 21$ & $\mathrm{O}$ & 0.419 & $+\mathrm{Ve}$ \\
\hline 15 & $\mathrm{Am} \mathrm{O} 22$ & Asia 1 & 0.123 & $+\mathrm{Ve}$ \\
\hline 16 & $\mathrm{Am} \mathrm{O} 23$ & Asia 1 & 0.663 & $+\mathrm{Ve}$ \\
\hline 17 & Am 082 & $\mathrm{O}$ & 0.969 & $+\mathrm{Ve}$ \\
\hline 18 & $\mathrm{Am} \mathrm{O83}$ & $\mathrm{O}$ & 0.999 & $+\mathrm{Ve}$ \\
\hline 19 & $\mathrm{Am} \mathrm{O84}$ & $\mathrm{O}$ & 1.107 & $+\mathrm{Ve}$ \\
\hline 20 & Am 085 & $\mathrm{O}$ & 0.774 & $+\mathrm{Ve}$ \\
\hline 21 & $\mathrm{Am} \mathrm{O73}$ & Asia 1 & 0.712 & $+\mathrm{Ve}$ \\
\hline 22 & Am O126 & $\mathrm{A}$ & 0.435 & $+\mathrm{Ve}$ \\
\hline 23 & Am 0.099 & $\mathrm{O}$ & 0.916 & $+\mathrm{Ve}$ \\
\hline
\end{tabular}


Proceeding of the Eleventh Veterinary Scientific Conference, 2012; 53-55

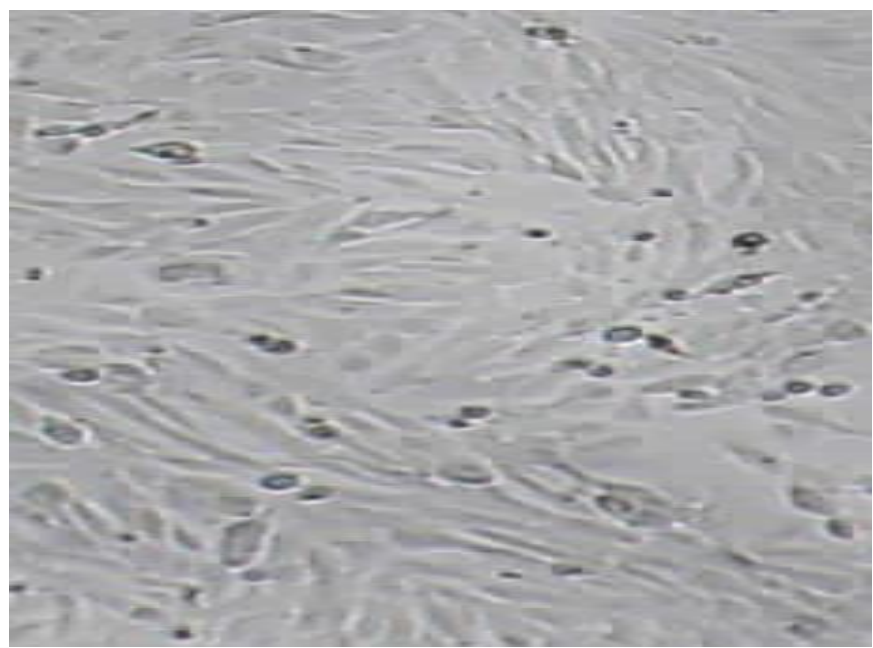

Figure 1: secondary fetal ovine thyroid cell (control) $10 \mathrm{X}$

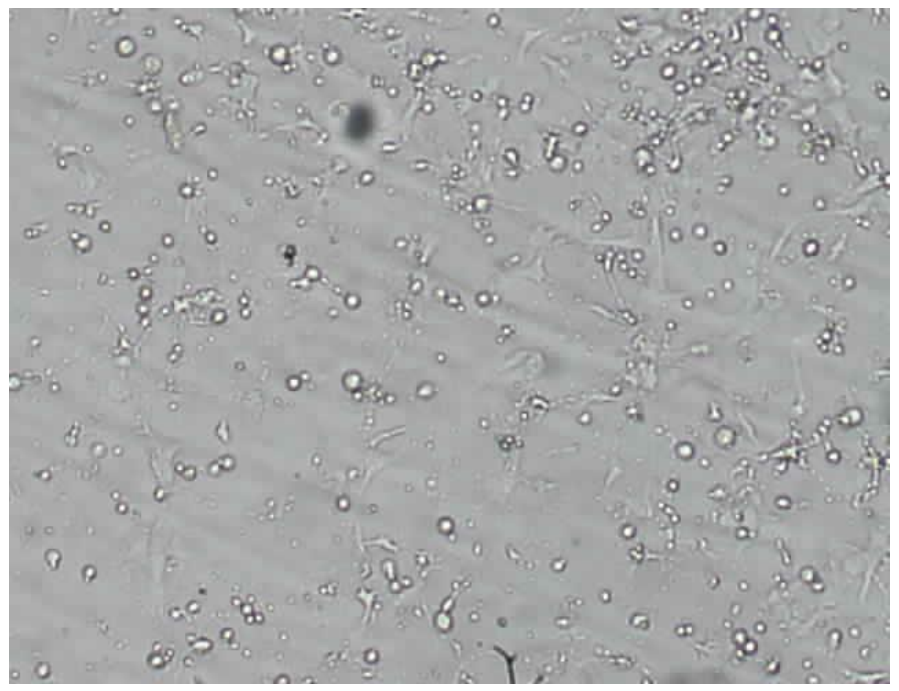

Figure 2 culture of secondary fetal ovine thyroid cells infected with FMDV (sample FMD Amoo3) $10 \mathrm{X}$

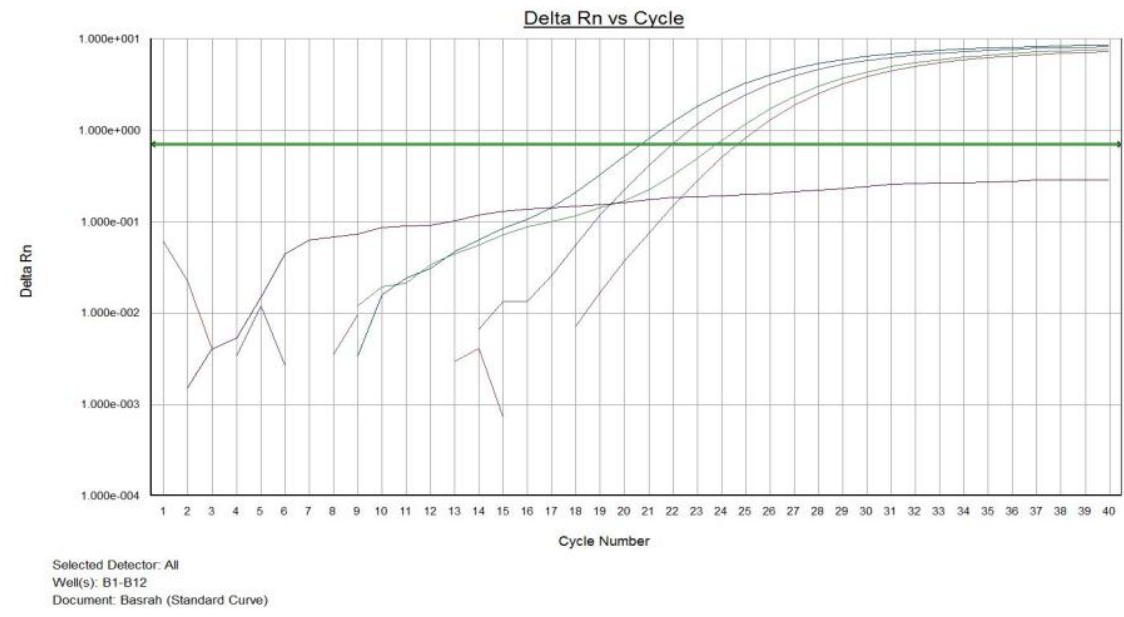

Figure 3: The result of rRT-PCR in four tested samples which show the Logarithmic fluorescence plots versus cycle number resulting from the determination of FMDV RNA.

\section{Discussion}

The possibility of using rapid sensitive and specific assays for FMD recognition is a prerequisite it for prevention, control and eradication of the disease. To isolate the FMD virus, 


\section{Proceeding of the Eleventh Veterinary Scientific Conference, 2012; 53-55}

the primary bovine thyroid cell culture is the most sensitive system for FMDv detection this view was confirmed by several another's and our previous and recent studies, in agreement with ,but second passage of the cells did not show any Cytopathic effect for three successive passages $(4,9,19,23)$ Continuous supply of these cells for diagnostic purposes is not easy because needs both :technical 7 professional preparation .However, when the supply is inadequate, the cells demonstrating comparable similarity in sensitivity may be utilized as we used several types of cell culture for isolation of FMDv and checked the sensitivity of the cells which produced visible CPE. The CPE showed on primary ovine thyroid cells, beside secondary ovine thyroid cells and the other sub passages showed distinctive CPE in less than 20 hours PI. the high sensitivity of the OTY and other cells tested.

The virus isolation and Ag detection by ELISA are considered the gold tests for diagnosis of FMD (6).However the development of research techniques involving Molecular Biology enabled the use of RT-PCR and real time PCR (rRT-PCR), (7, 15, 16, and 20). Assay for the detection of FMDv genetic materials in various biological samples. The rRT-PCR assay is currently regarded the most modern analytical method detecting reaction products by emitting fluorescence in each cycle and enables the elimination of Agarose gel electrophoresis. The use of this method in FMD diagnosis was described in several reports in which another presented its high sensitivity accrue, usefulness and time saving $(6,14,18)$.

To utilize this method for our study we use primers and fluorescence probe selected from the IRES region of FMDv genome specific for detection of the seven FMDv serotypes and by this method we where abele to detect FMDv RNA in all tested samples (23 samples ) (21). This indicates a highand comparable sensitivity and usefulness of these methods. However, several authorizes reported a higher sensitivity of the rRT-PCR assay in comparison to that of combined result both virus isolation and Ag-ELISA.(22).

The data from the literatures have highlights that PCR assay are more frequently used for FMD diagnosis where as the virus isolation is becoming rarely applied (21).However, as it was mentioned previously, FMD belongs to the most contagious infectious diseases with regard to its epizootic and economic impact. Thus, diagnostic examinations should not be limited to one method it seems reasonable to use PCR virus isolation assays to increase the effectiveness of recognition and to check mutually the results .More ever the isolation of the virus from the disease outbreak enables obtaining the material for a further characteristic of isolates and the disease immunoprophylaxis the presented results show that the used methods permit an effective detection of FMDv in biological materials.

\section{References}

1. Acharya R, Fry E, Stuart D.(1989). The three-dimensional structure of foot and mouth disease virus at 2.9A resolution. Nature., 337:709-716.

2. Al-Bana, A.S. and Shouny, M.O.(1988).Foot and mouth disease in Iraqi native gazella:virus isolation Serotyping and characterization. The Iraqi J.Vet. Med., 12:13-24.

3. Al-Janabi, M.A. (2001).Isolation and identification of Foot and Mouth Disease virus from cattle and sheep and study the infectivity of the virus of different types of cells from human and animals. MSc Thesis In Veterinary Microbiology, College of Veterinary Medicine, University of Baghdad. (In Arabic).

4. Brhm, K.E.; Ferris, N.P.; Lenk, M., Riebe, R. and Haas, B. (2009). Highly sensitive fetal goat tongue cell line for detection and isolation of foot - and- mouth disease virus. J Clin Microbiol., 10:3156-3160.

5. Bittle, JL.; Houghten, RA. and Alexander, H . (1982). Protection against foot-and-mouth disease by immunization with a chemically synthesized peptide predicted from the viral nucleotide sequence. Nature., 298:30-33.

6. Callahan J.D., Brown F., Osrio F.A., Sur J.H., Kramer E., Long G.W., Lubroth J., Ellis S.j., Shoulars K.S., Gaffney K.L., Rock D.L., Nelson W.M.(2002) use of a portable real-time 


\section{Proceeding of the Eleventh Veterinary Scientific Conference, 2012; 53-55}

reverse transcriptase-polymerase chain reaction assay for rapid detection of foot-and-mouth disease virus. J Am Vet Med Assoc 2002, 220, 1636-1642.

7. Clavjo A., Viera-Pereira P.J., Pergmann I.(2003)use of the reverse transcription polymerase chain reaction (RT-PCR) for the rapid diagnosis of foot-and-mouth disease in south America. Vet Res commun 2003, 27, 63-71.

8. FAO(1999)" Brighf note, The Iraqi Representation", 40-41.

9. Ferris N.P., King D.P., Reid S.M., Hutchings G.H., Shaw A.E., Paton D.J., Goris N., Haas B., Hofimann, Brocchi E., Bugnetti M., Dekker A., De Clereq K.(2006) foot-and-mouth disease viris: a first inter-laboratory comparison trial to evaluate virus isolation and RT-PCR detection method. Vet Microbial 2006, 117, 130-140.

10. Food And Agricultural Organization Of The United Nations (Fao) (1997). Potency assessment of inactivated viral vaccines. In: FAO Animal Production and Health Series No 35. Vaccine Manual. The Production and Quality Control of Veterinary Vaccines for use in Developing Countries, Mowat N. and Rweyemamu M., eds. FAO, Rome, Italy, 395-409.

11. Fross, S.; Strebel, K.; Beck, E. and Scaller, H. (1984). Nucleotide sequence and genomic organization of foot and mouth disease virus. Nucleic Acids Res 12:6587-6601.

12. Iah-P.Ep-Meg-For- 005-1 Wrl Ref. No. Irq/24/2009.

13. Goris, N.; Merkelbach-Peters, P.; Diev, V.I.; Verloo, D.; Zakharov, V.M.; Kraft, H.P. and De Clercq, K. (2007). European Pharmacopoeia foot-and-mouth disease vaccine potency testing in cattle: between test variability and its consequences. Vaccine, 25: 3373-3379.

14. KingD.P., Ferris N.P., Shaw A.E., Reid S.M.,hutchings G.H., Giuffre A.C., Robida J.M., Callahan J.D., Nelson W.N., Beckham T.R.(2006) detection of foot-and-mouth disease virus: comparative diagnostic sensitivity of two independent real-time reverse transcription polymerase chain reaction assay. J. Vet. Diagn. Invest., 18: 93-97.

15. King, D.P.; Dukes, J.P.; Reid, S.M.;Ebert, k.; Shaw, A.E.; Mills, C.E.; Boswell, L. and Ferris, N.P.(2008) prospects for rapid diagnosis of foot-and-mouth disease in the field using reverse transcriptase-PCR. Vet Rec., 162:315-316.

16. Orsel K., Roest H.I., Elzinga-bril E.M., Hemert-Kliutenberg F., Dekker A.(2008) detection of foot-and-mouth disease virus in infected pigs by RT-PCR four weeks after challenge. Vet Rec., 162: 753-754.

17. Logan D, Abu-Ghazaleh, Blackmore W.(1993). Structure of a major immunologic site on foot-and-mouth disease virus. Nature., 362:566-568.

18. Paixao T.A., Carvalho Neta A.V., Paiva N.O., Reis J.R., Barbosa M.S., Serra C.V., Silva R.R., Beckham T.R., Martin B.M., Clarke N.P., Adams L.G., Santos R. L.(2008). Diagnosis of foot-and-mouth disease by real-time reverse transcription polymerase chain reaction under field conditions in BRAZIL. MBC Vet. Res., 4:53.

19. Paprocka, G. (2008). Isolation and identification of foot-and-mouth disease virus. Medycyna Wet., 64: 1404-1406.

20. Reid, S.M.; Ferris, N.P.; Hutchings, G.H.; Samuel, A.R. and Knowles, N.J.(2000). Primary diagnosis of foot-and-mouth disease by reverse transcription polymerase chain reaction. J. Virol. Methods, 89: 167-176.

21. Reid S.M., Ferris N.P., Hutchings G.H., Zhang Z., Belsham G., Alexandersen S.(2002). Detection of all seven serotypes of foot-and-mouth disease virus by real-time, flourogenic reverse transcription polymerase chain reaction assay. J Virol Meth., 105, 67-80.

22. Shaw A.E., Reis S.M., King D.P., Hutchings G.H., Ferris N.P.(2004) Enhanced laboratory diagnosis of foot-and-mouth disease by real-time polymerase chain reaction. Rev Sci Tech Off Int. Epiz., 23:1003-1009

23. Snowdon, W.A. (1966). Growth of foot-and-mouth disease virus in monolayer cultures of calf thyroid cells. Nature., 210:1079-1080. 